Hsueh Qu

National University of Singapore

phiqhm@nus.edu.sg
Original Scientific Paper

UDC 165 Хјум Д.

$165.7 / .8$

14 Хјум Д.

\title{
HUME AND RELIABILISM
}

\begin{abstract}
Hume's epistemological legacy is often perceived as a predominantly negative sceptical one. His infamous problem of induction continues to perplex philosophers to this day, and many of his sceptical worries maintain their interest in contemporary eyes (e.g. with regard to reason, the senses, substance, causation). Yet Hume's positive epistemological contributions also hold significance for philosophy in this day and age. In this paper, I aim to situate Hume's epistemology in a more contemporary context, particularly with regard to the theme of reliabilism that runs throughout this epistemology. This will take the shape of examining correspondences and contrasts between Hume's epistemologies in the Treatise and Enquiry and reliabilism, as well as an examination of how Hume's framework might handle some major challenges for reliabilist epistemologies. In particular, I argue that that while Hume is tempted to an epistemology that is intimately tied to truth in the Treatise, he backs away when confronted with the excesses of scepticism in the conclusion of Book 1 , and winds up with an epistemology most similar to the contemporary epistemological frameworks of dogmatism and phenomenal conservatism. Yet, largely because of his reliance on the passions (a respect in which he diverges from these two contemporary frameworks), the epistemology of the Treatise remains crucially dissociated from truth. Meanwhile, in the first Enquiry, he proceeds to develop a two-tiered epistemological framework that first accords all our justification with default authority, and then founds all-things-considered epistemic justification on our evidence for the reliability of our faculties. The first tier most resembles the contemporary epistemological framework of conservatism, while the second tier most closely resembles approved-list reliabilism. In this, a clear reliabilist thread runs through the epistemology of the Enquiry. I will also argue that although Hume did not appear to fully appreciate one of the most significant challenges for reliabilism - that is, the generality problem-his philosophical framework nevertheless contains the beginnings of a response to it.
\end{abstract}

Keywords: Hume, scepticism, externalism, internalism, reliabilism

\section{Introduction}

Hume's epistemological legacy is often perceived as a predominantly negative sceptical one. His infamous problem of induction continues to perplex philosophers to this day, and many of his sceptical worries maintain their interest in contemporary eyes (e.g. with regard to reason, the senses, substance, causation). Yet Hume's positive epistemological contributions also hold significance for philosophy in this day and age. In this paper, I aim to situate Hume's epistemology in a more contemporary context, 
particularly with regard to the theme of reliabilism that runs throughout this epistemology. This will take the shape of examining correspondences and contrasts between Hume's epistemologies in the Treatise and Enquiry and reliabilist frameworks, as well as an examination of how Hume's system might handle some major challenges for reliabilist epistemologies. This paper thus builds on my previous monograph investigating the epistemological differences between the Treatise and the Enquiry. ${ }^{1}$ While the core of my position has not substantively changed, this paper, unlike the monograph, explores the differences between these works through the particular lenses of reliabilism. It also develops my views in various respects, notably in more deeply exploring Hume's correspondences with contemporary epistemological frameworks, and formulating a more thorough response on Hume's behalf to the generality problem. Notably, this paper also represents a shift in my own views on Hume and externalism: unlike in my earlier work, this paper sees the Enquiry as having externalist tendencies, suitably qualified. ${ }^{2}$

Intuitively, epistemological justification must be, in some way, shape or form, related to truth. What is the point of pursuing epistemic justification if doing so does not make us more likely to believe true things? Reliabilism looks to draw as straight as possible a line between these two notions. ${ }^{3}$ There is a tremendous variety of such accounts, but very broadly, process reliabilism takes a belief to be justified if it proceeds from a reliable or truth-conducive process.

Process reliabilism is typically taken to be externalist in nature-after all, what matters isn't one's evidence for a belief, but whether the belief proceeds from a process that is in fact reliable. ${ }^{4}$ However, this may be disputed, as we will see. For one, a number of reliabilist accounts have adopted internalistfriendly elements. And some internalist accounts have adopted the mantle of reliabilism. In this paper, I use 'reliabilism' to encompass internalist accounts that tie epistemological justification to truth-conduciveness in an intimate way. Even if one wishes to maintain that process reliabilism is a distinctively externalist account, it cannot be denied that it has a core insight that can be adopted by internalist accounts, which is that epistemological justification closely concerns in some respect the truth-conduciveness of doxastic processes.

\footnotetext{
1 (Qu, 2020).

2 (Qu, 2018b) and (Qu, 2020).

3 Reliabilism has gained a great deal of prominence in contemporary epistemology. The classic statement of reliabilism about justification is (Goldman, 1979). Important early statements of reliabilism about knowledge are (Goldman, 1967) and (Dretske, 1981).

4 How to characterise the internalist/externalist distinction is itself a matter of some dispute, but for the purposes of this paper a sensible way to draw the distinction might be as follows: an epistemology is internalist iff a person either has access or potential access to the basis for their epistemic justification. This form of internalism is referred to as 'accessibilism' in (Feldman \& Conee, 2001). (Beddor and Goldman, 2015) argue that since 'being reliably caused' is neither a mental state nor directly accessible to the believer, process reliabilism must be an externalist theory.
} 
Hume agrees with the process reliabilist about the epistemic primacy of doxastic processes, as opposed to, say, evidence or belief. In the moral case, Hume argues that strictly speaking, it is not our actions that are the basis for moral evaluation, but rather the underlying characters that produce them (THN 2.3.2.6, THN 3.3.1.4; SBN 411, 575). ${ }^{5}$ For Hume, moral evaluations are based on durable character traits. The intuition here seems to be something like as follows. A person cannot be praised or blamed at time $t$ for a quality that they do not possess or instantiate at time $t$. Since actions are transient, we cannot blame someone for an action they have committed in the past. However, moral evaluations are more persistent than actions, and thus the latter cannot be the basis for the former. Instead, the durable basis upon which we are to be morally evaluated is the underlying stable character traits or dispositions that give rise to these actions. Since we cannot directly observe these character traits, they must be inferred on the basis of a person's actions (EHU 8.31; SBN 99). ${ }^{6}$

Hume's epistemological framework is unfortunately much less explicit than his moral one. ${ }^{7}$ But there seems little reason not to apply the same line of thought here. Beliefs are lively ideas (THN 1.3.7.6; SBN 97); being occurrent, they are, like actions, transient. ${ }^{8}$ This lack of durability precludes them from being the basis of epistemic evaluation. ${ }^{9}$ The proper basis of epistemic evaluation is instead the underlying stable dispositions or processes that produce these beliefs-reason, custom, the imagination, and so forth. ${ }^{10}$

We have seen that Hume agrees with the process reliabilist that epistemic justification turns on belief-forming processes. But does he agree that their truth-conduciveness is the crucial normative property of these processes? I will argue that he is tempted to such a view in the Treatise, although he backs away when confronted with the excesses of scepticism in the conclusion of Book 1. However, in the first Enquiry, he proceeds to develop a twotiered epistemological framework that founds epistemic justification on our evidence for the reliability of our faculties. I will also argue that although

5 In references to Hume's texts throughout the paper, 'THN' refers to the Treatise of Human Nature, 'EHU' to the Enquiry Concerning Human Understanding, and 'EPM' to the Enquiry Concerning the Principles of Morals,. Arabic numerals refer to section and paragraph numbers (EHU and EPM), or to book, part, section, and paragraph numbers (THN). SBN numbers refer to numbers in the Selby-Bigge edition of these works.

$6 \quad(\mathrm{Qu}, 2017, \mathrm{p} .84)$.

7 Perhaps this is because, as (Loeb, 2011) and (Ainslie, 2015) argue, Hume's epistemology occurs primarily in service of his psychology. I agree that this is true for the Treatise $(\mathrm{Qu}$, 2020, p.26).

8 (Loeb, 2002) argues that Hume is fundamentally committed to a dispositional account of beliefs, but see (Marusic, 2010) for a convincing criticism of this view.

9 (Greco, 2012, Ch.9) argues for a virtue-theoretic epistemology on very similar grounds.

10 (Qu, 2014b, pp.515-516). (Schmitt, 2014) attributes this view to Hume on other grounds (i.e. inheriting it from his predecessors such as the Cartesians and Locke), calling it an 'operations-based epistemology' (p.28). 
he did not appear to fully appreciate one of the most significant challenges for reliabilism - that is, the generality problem-his philosophical framework nevertheless contains the beginnings of a response to it.

\section{Truth-conduciveness in the Treatise}

Over the years, various commentators have defended reliabilist readings of the Treatise. (Costa, 1981) was an early proponent, and (Beebee, 2006, p.73) briefly suggests reading Hume as an inductive reliabilist. However, it is safe to say that none have done more to advance the reliabilist reading of Hume than (Schmitt, 2014). Briefly, Schmitt argues that Hume's epistemological motivations are to maintain that demonstrative reasoning and probable reasoning have comparable, and laudable, epistemic status. Yet, the two belief-forming processes are intrinsically very different (p.22), and so their epistemological commonality must derive from their extrinsic features instead. Schmitt proposes that the relevant extrinsic feature is reliabilityalthough they issue from very different psychological processes, these processes have in common their tendency to produce true beliefs.

Rather than particular snippets of text, the strength of Schmitt's framework rests more on the overarching narrative it imbues upon Book 1 , to which I cannot do justice here. Still, some brief textual evidence is as follows. Schmitt argues persuasively that beliefs have a natural function to facilitate the avoidance of calamities (THN 1.3.10.2; SBN 118-9), and that they fulfil this natural function by delivering truth. ${ }^{11}$ Correspondingly, the natural function of our belief-forming processes is to deliver true beliefs. ${ }^{12}$ Moreover, Hume frequently associates 'just' and its converse with truth and falsity (THN 1.2.4.17, THN 1.4.1.1, THN 1.4.7.13, THN 2.1.3.7, THN 2.3.10.2, THN App.1; SBN 41-2, 180, 271-2, 282, 448-9, 623). ${ }^{13}$ More can be said on this point, but at the very least, it seems that Hume recognises that epistemology should not be divorced from truth.

For the most part, I agree that Hume in the Treatise seeks an epistemology closely tied with truth. Nevertheless, I will briefly adduce some reasons, sourcing from the conclusion of Book 1, to think that when confronted with the excesses of scepticism, Hume becomes decidedly pessimistic about the prospects for such an epistemology, and correspondingly retreats. ${ }^{14}$

Hume faces an epistemological reckoning in the conclusion of Book 1. He frames his primary sceptical worry as a dissociation from truth:

Can I be sure, that in leaving all establish'd opinions I am following truth; and by what criterion shall I distinguish her, even if fortune

\footnotetext{
11 (Schmitt, 2014, p.108).

12 (Schmitt, 2014, p.112).

13 (Schmitt, 2014, Ch.4).

14 (Qu, 2020, pp.159-166).
} 
shou'd at last guide me on her foot-steps? After the most accurate and exact of my reasonings, I can give no reason why I shou'd assent to it; and feel nothing but a strong propensity to consider objects strongly in that view, under which they appear to me.... Without this quality, by which the mind enlivens some ideas beyond others (which seemingly is so trivial, and so little founded on reason) we cou'd never assent to any argument, nor carry our view beyond those few objects, which are present to our senses. (THN 1.4.7.3; SBN 265)

The concern is essentially that there does not seem to be a reliable link between our ideas being lively and their being true. Hume lists habit, the memory, the senses, and the imagination as being hostages to fortune in this respect. Essentially, virtually all our belief-forming processes share this epistemically unfortunate dependence of vivacity, leaving us with little reason to think they are indeed truth-conducive.

One thing to note at this juncture is that Hume's framing of this issue here indicates that his epistemological concern is internalist rather than externalist in nature. His worry is not whether our belief-forming processes are in fact reliable. His worry is rather that we have no reason (and here he seems to mean an introspectively available reason-'I can give no reason') to think that they are reliable. While this is perhaps not decisive, it is at least suggestive.

How then does Hume resolve his sceptical problems? I lack the space to enter into a detailed analysis of THN 1.4.7 (SBN 263-7); I do so elsewhere, and will be brief here. ${ }^{15}$ Having been left with no reason to think our beliefforming processes reliable, Hume is at a loss as to which of them to depend on. This culminates in the 'dangerous dilemma' (THN 1.4.7.6-7; SBN 267-8), which can be stated as follows: should we assent only to the trivial suggestions of the imagination, or should we instead adhere wholly to the dictates of the understanding? The former (the 'credulity horn') leads to 'errors, absurdities, and obscurities', while the latter (the 'sceptical horn') leads to the utter annhilation of our beliefs, given the sceptical regress of THN 1.4.1 (SBN 1807), which can only be avoided by the aforementioned trivial propensities. Solutionless, Hume stumbles into melancholy and delirium (THN 1.4.7.9; SBN 269), followed by a period of 'spleen and indolence' (THN 1.4.7.11; SBN 270). Near the end of this period, Hume presents what has, following Garrett, become known as the 'Title Principle': 16

15 (Qu, 2014b), (Qu, 2020, Chs. 6-7).

16 While controversial, the centrality of the Title Principle to Hume's response to scepticism has many defenders in the literature. See for instance Garrett in (Garrett, 1997, pp.233237), (Garrett, 2006), (Garrett, 2015, pp.27-237), and (Garrett, 2016); (Mounce, 1999, p.60); (Kail, 2007, p.70); (Allison, 2008, pp.323-330); (Meeker, 2013, pp.73-81); (Qu, 2014b) and (Qu, 2020); (Schafer, 2014); (Schmitt, 2014, pp.368-375); (Baxter, 2018, pp.388-389), and (Sasser, Forthcoming). 
Where reason is lively, and mixes itself with some propensity, it ought to be assented to. Where it does not, it never can have any title to operate upon us. (THN 1.4.7.11; SBN 270)

Notably, the Title Principle navigates the two horns of the dangerous dilemma. The credulity horn is avoided, since we do not wholly assent to the beliefforming trivial propensities of the imagination, but allow for reason to play a central role. And the sceptical horn is avoided, since the iterative reasoning that engenders the doxastic apocalypse is devoid of any liveliness, and is shunned by our propensities. Thus, the Title Principle licenses Hume's return to philosophical reasoning, when conjoined with the return of his passions or curiousity and ambition (THN 1.4.7.12; SBN 270-1): such reasoning is lively and mixes with these two propensities. ${ }^{17}$

The Title Principle, in emphasising the role of the liveliness or vivacity of our beliefs, has affinities with certain brands of permissive foundationalism that tie justification to a certain phenomenal character. Most prominent among this family of views include Huemer's 'phenomenal conservatism', and Pryor's 'dogmatism. ${ }^{18}$ Phenomenal conservatism holds that epistemic justification is conferred by seemings or appearances-the fact that it appears as though $\mathrm{P}$ provides some prima facie justification for $\mathrm{P}$. The notion of a seeming has distinct parallels with Hume's notion of liveliness, since to have a lively idea (that is, a belief) is for the idea to appear as true. And like vivacity (THN 1.3.7.7; SBN 628-9), seemings are phenomenal, ${ }^{19}$ and unanalysable. ${ }^{20}$ Just as a seeming carries epistemic justification for Huemer, so too does liveliness as per the Title Principle. Of course, there are differences. Notably, Huemer treats seemings as distinct mental states from beliefs, whereas Hume takes vivacity to be constitutive of belief. ${ }^{21}$ But the core insight, that some mental states enjoy epistemic justification at least partly in virtue of their phenomenal force, seems to be shared between the Title Principle and phenomenal conservatism.

17 Thus, by 'propensities', Hume seems to mean the passions. See (Schafer, 2014, p.9) and (Qu, 2020, p.128), but refer to (Durland, 2011, pp.82-83) for disagreement.

18 See (Huemer, 2001), (Huemer, 2007), (Huemer, 2013) and (Pryor, 2000), (Pryor, 2004). Similar views are defended by (Tucker, 2010), (Brogaard, 2013), and (Chudnoff, 2013), among others.

19 Huemer describes appearances as having 'forcefulness' (Huemer, 2001, p.77) and 'assertive' character (Huemer, 2013, p.329), which suggests their having a phenomenal dimension. However, he denies that 'appears' takes a phenomenal use, although this seems driven by the implausibility of appearances always carrying a certain sensory quale (Huemer, 2013, p.330), which is consistent with appearances nevertheless having a non-sensory phenomenal feel. (Tolhurst, 1998, p.298) refers to the 'felt veridicality' of seemings, and the phenomenal dimension of seemings is asserted by (Tucker, 2010, p.530), (Werner, 2014, p.1765), and (McAllister, 2018, p.3082), to name a few.

20 (Huemer, 2013, pp.328-329).

21 (Huemer, 2007, p.31). 
Meanwhile, dogmatism is the position that our perceptual beliefs are immediately prima facie justified by their phenomenology. As with seemings, the distinctive justification-conferring phenomenology is one that presents its contents as true. ${ }^{22}$ Again, there are differences: dogmatism typically takes only perceptual beliefs to enjoy such justification, whereas the Title Principle extends its domain to all beliefs. ${ }^{23}$ But again, there is a shared core insight between the two: certain phenomenologies can confer epistemic justification. $^{24}$

Note that the Title Principle, like phenomenal conservatism and dogmatism, has a distinctly internalist character. ${ }^{25}$ It founds epistemic justification on vivacity and the passions. The former component, insofar as it is an experiential component of our perceptions, is clearly introspectable. As for the latter, our passions have a distinctive qualitative character, insofar as they are impressions of reflection (THN 1.1.2.1, THN 1.1.6.1, THN 2.1.1.1; SBN 7-8, 15-16, 275). ${ }^{26}$ The factors that confer epistemic justification are ones that are mentally available to us.

At the same time, the Title Principle seems to veer away from the straight and narrow path of an epistemology founded on truth-conduciveness. For one, Hume does not justify the Title Principle on the basis that the relevant belief-forming process (of reason mixing with some propensity) is reliable; indeed, he does not offer any justification for it at all. ${ }^{27}$

Moreover, while we examined the contemporary significance of Hume's tying epistemic justification to liveliness via the Title Principle, it should not be forgotten that the Title Principle also insists on tying epistemic justification to our propensities or passions, a move which has a markedly less storied legacy in contemporary epistemology. Importantly, our propensities do

22 (Pryor, 2004, p.357).

23 (Teng, 2018) has recently objected to dogmatism on the basis that the justificationconferring phenomenology of perceptions is one that is psychologically shared with mere imaginings, and this feature of imaginings fails to confer justification. This psychological observation coheres well with Hume's framework, whereby the difference between merely imagined ideas and beliefs boils down to the degree of vivacity present in the perception.

24 The link between Pryor's dogmatism and the Title Principle is observed in (Garrett, 2015, p.244), (Qu, 2014a, p.28), and (Qu, 2020, p.222).

25 Hume would probably not be very friendly towards reliabilist twists on such views that relate seemings with truth-conduciveness. For Hume himself casts major doubt on whether vivacity can be said to meaningfully co-vary with truth (THN 1.4.7.3).

26 Some commentators have argued that the calm passions lack any qualitative character whatsoever, for instance (Stroud, 1977, p.164), (Shaw, 1989), and (Smith, 1994, p.112). I have argued in $(\mathrm{Qu}, 2018 \mathrm{a})$ that this is incorrect-although they are less emotionally intense than the violent passions, Hume says that they have 'little emotion', and not 'no emotion' (THN 2.3.3.8); moreover he explicitly takes them to be prone to confusion with the determinations of reason precisely because 'their sensations are not evidently different' (ibid., emphasis added).

27 (Durland, 2011, pp.83-84), (Millican, 2016, p.105), (Qu, 2020, pp.147-152). 
not seem particularly truth-conducive. Bill's desire for his daughter to be successful might cause him to falsely believe that she is doing better than she is; Mary's ambition might cause her to falsely believe unreliable gossip that she is to be promoted. An epistemology that accords our propensities a central role seems to have little in common with reliabilism. Importantly, this abandonment of truth-conduciveness does not appear to be accidental. Consider the problematic argument of THN 1.4.1 (SBN 180-7) that engendered the sceptical horn of the dangerous dilemma. Hume never takes issue with the argument's cogency, but only argues that it cannot have any psychological effect (THN 1.4.1.7; SBN 183). And the same is true of his sceptical argument with regard to the senses in THN 1.4.2 (SBN 187-218):

Tis impossible upon any system to defend either our understanding or senses; and we but expose them farther when we endeavour to justify them in that manner. As the sceptical doubt arises naturally from a profound and intense reflection on those subjects, it always encreases, the farther we carry our reflections, whether in opposition or conformity to it. Carelessness and in-attention alone can afford us any remedy. (THN 1.4.2.57; SBN 218)

It seems that Hume blunts the sceptical force of these arguments not by denying their truth, but by appealing to our propensities, which, notoriously, are epistemically unreliable.

This is borne out in THN 1.4.7 (SBN 180-7). Just prior to endorsing the Title Principle, Hume notes that philosophical reasoning does not offer 'any tolerable prospect of arriving... at truth and certainty' (THN 1.4.7.10; SBN 269-70). And at the conclusion of THN 1.4.7 (SBN 180-7), Hume resigns himself to a philosophical system that is dissociated from truth:

But were these hypotheses once remov'd, we might hope to establish a system or set of opinions, which if not true (for that, perhaps, is too much to be hop'd for) might at least be satisfactory to the human mind, and might stand the test of the most critical examination. (THN 1.4.7.14; SBN 272)

Here, Hume goes so far as to say that the establishment of a true system is 'too much to be hoped for'-all that we can aspire to is that such a system stands up to 'the most critical examination.28

This is of course not to say that Hume's reasonings cannot be true. But the crucial point is that his epistemology dissociates epistemic justification from truth in grounding it on factors that are not truth-tracking. To sum up,

28 Hume does hope to 'contribute a little to the advancement of knowledge', but this contribution does not lie in the discovery of truth per se, but only in 'giving in some particulars a different turn to the speculations of philosophers, and pointing out them more distinctly those subjects, where alone they can expect assurance and conviction' (THN 1.4.7.14; SBN 273). 
in the Treatise, Hume reluctantly abandons the prospects of an epistemology founded on reliability. He does not abandon an externalist epistemology, but only because it did not appear to be on the cards to begin with.

\section{Reliabilism in the Enquiry}

There is, I venture, a stronger and more sustained theme of reliabilism that runs through the first Enquiry. First, consider Section 5. ${ }^{29}$ Having presented his famous argument regarding induction in Section 4, he begins Section 5 by seeking to reassure readers who might be worried about its sceptical implications:

Nor need we fear, that this philosophy, while it endeavours to limit our enquiries to common life, should ever undermine the reasonings of common life, and carry its doubts so far as to destroy all action, as well as speculation. Nature will always maintain her rights, and prevail in the end over any abstract reasoning whatsoever. Though we should conclude, for instance, as in the foregoing section, that, in all reasonings from experience, there is a step taken by the mind, which is not supported by any argument or process of the understanding; there is no danger, that these reasonings, on which almost all knowledge depends, will ever be affected by such a discovery. If the mind be not engaged by argument to make this step, it must be induced by some other principle of equal weight and authority; and that principle will preserve its influence as long as human nature remains the same. What that principle is, may well be worth the pains of enquiry. (EHU 5.2; SBN 41-2)

This passage reveals two things. First, the argument of Section 4 is not a merely psychological one, but has an epistemological dimension. ${ }^{30}$ Hume here is addressing the concerns of readers who are worried about the scope of the scepticism of Section 4: he notes that his brand of academical philosophy will not 'carry its doubts so far as to destroy all action, as well as speculation' - which is to say, it does carry doubts in the first place. Second, having denied induction any justification sourcing from reason in Section 4, Hume looks to address any profound sceptical implications by offering an alternative source of justification: 'If the mind be not engaged by argument to

29 I also discuss these issues in (Qu, 2014a) and (Qu, 2020, Ch.4).

30 For instance, 'descriptivist' accounts of THN 1.3.6 that see it as merely making a psychological point can be found in (Broughton, 1983), (Garrett, 1997, pp.91-95), (Garrett, 1998), (Owen, 1999), (Noonan, 1999), and (Allison, 2008, Chapter 5). Normative interpretations include (Winkler, 1999), (Loeb, 2006), (Loeb, 2008), (Millican, 1995), (Millican, 2002), (Qu, 2014a), and (Dimech, Forthcoming). I have suggested that the Treatise's version is descriptive while the Enquiry's is normative in $(\mathrm{Qu}, 2020$, Chs.34), but I bracket this issue for the purposes of this paper. 
make this step, it must be induced by some other principle of equal weight and authority'. 'Authority' in particular certainly seems to carry significant normative import-since our inductive practices are not produced by reason, which would offer them a certain form of justification, Hume will argue that they are produced by another belief-forming process that carries as much justification (albeit of a different form) as reason.

This belief-forming process is 'Custom, or Habit' (EHU 5.5; SBN 43). On what basis does custom carry this equal authority to reason? Hume expounds on this at some length at the close of Section 5:

Here, then, is a kind of pre-established harmony between the course of nature and the succession of our ideas; and though the powers and forces, by which the former is governed, be wholly unknown to us; yet our thoughts and conceptions have still, we find, gone on in the same train with the other works of nature. Custom is that principle, by which this correspondence has been effected; so necessary to the subsistence of our species, and the regulation of our conduct, in every circumstance and occurrence of human life. (EHU 5.21; SBN 54-5)

In making an admittedly sardonic reference to the 'pre-established harmony' that obtains between our inductive beliefs and the progression of nature via the mechanism of custom, Hume is explicitly referencing the truth-conducive nature of this subfaculty: the beliefs produced by custom tend to be true, and this is why it is a principle of 'equal weight and authority' to reason. Indeed, if anything, Hume goes on to claim that custom is superior to reason in this respect:

...this operation of the mind, by which we infer like effects from like causes, and vice versa, is so essential to the subsistence of all human creatures, it is not probable, that it could be trusted to the fallacious deductions of our reason, which is slow in its operations; appears not, in any degree, during the first years of infancy; and at best is, in every age and period of human life, extremely liable to error and mistake. It is more conformable to the ordinary wisdom of nature to secure so necessary an act of the mind, by some instinct or mechanical tendency, which may be infallible in its operations, may discover itself at the first appearance of life and thought, and may be independent of all the laboured deductions of the understanding. (EHU 5.22; SBN 55)

Reason is 'fallacious' and 'extremely liable to error and mistake'; custom, in having a correspondence with the course of nature, demonstrates a marked superiority in this regard.

(Dauer, 1980, p.363) and (Kail, 2016, p.152) take the conclusion of Section 5 to indicate that Hume endorses a reliabilist account in the Enquiry. Meanwhile, (Loeb, 2008, p.117) takes it to establish an externalist epistemology, although he demurs about the particular form this externalist epistemology takes. While I take it to be clear that these passages endorse 
custom on the basis of its truth-conduciveness, it is underdetermined whether Hume commits himself to an externalist or internalist epistemology here. It is true that he claims that 'we are ignorant of those powers and forces' that determine the regular course of nature (EHU 5.22; SBN 55). But we are not ignorant of the fact that custom has a reliable track record: he emphasises that we 'we find' this correspondence between our inductive beliefs and nature to have obtained (EHU 5.21; SBN 54), which is suggestive that what justifies our reliance on custom is not so much that it is in fact truth-conducive, but rather that we find it to be such. To discern the epistemological framework that grounds this endorsement, we will now turn to Section $12 .{ }^{31}$

Hume's goal in this section is to determine what form of scepticism he should endorse. To this end, he dismisses a number of options, before finally endorsing his own mitigated scepticism. First, he dismisses antecedent scepticism, which doubts not only our beliefs, but also our faculties prior to any investigation as to their reliability:

There is a species of scepticism, antecedent to all study and philosophy, which is much inculcated by Des Cartes and others, as a sovereign preservative against error and precipitate judgment. It recommends an universal doubt, not only of all our former opinions and principles, but also of our very faculties; of whose veracity, say they, we must assure ourselves, by a chain of reasoning, deduced from some original principle, which cannot possibly be fallacious or deceitful. But neither is there any such original principle, which has a prerogative above others, that are self-evident and convincing: Or if there were, could we advance a step beyond it, but by the use of those very faculties, of which we are supposed to be already diffident. The Cartesian doubt, therefore, were it ever possible to be attained by any human creature (as it plainly is not) would be entirely incurable; and no reasoning could ever bring us to a state of assurance and conviction upon any subject. (EHU 12.3; SBN 149-50)

Hume raises a decisive objection to such a priori form of scepticism: without antecedently relying on our faculties, we could never hope to make any epistemic progress whatsoever. Thus, we are licensed to accord default or prima facie justification to our faculties. ${ }^{32}$ We might call such justification antecedent justification.

This epistemological framework closely resembles a form of what is called 'conservatism' endorsed by Wright. ${ }^{33}$ Wright suggests that we might be

31 See my (Qu, 2018b) and (Qu, 2020, Ch.9), which go into more textual depth, although this paper develops the contemporary significance of this text in more detail.

32 (Garrett, 2007, p.6), (Millican, 2012, p.59), (Qu, 2020, p.183).

33 (Wright, 2002), (Wright, 2004), (Wright, 2014). Wright distinguishes warrant or entitlement from justification, which is a distinction I will not make much of here. A view in this vicinity is endorsed by Burge, which argues that we have an unearnt right 
entitled to believe some foundational propositions on the basis of their being fundamental to our epistemological projects. These propositions, which he calls 'cornerstones' of a given region of thought, are characterised by being such that a lack of warrant for them entails a lack of warrant for any belief in this region. ${ }^{34}$ Since doubting such cornerstones would be epistemically ruinous, the epistemically dominant strategy is to accept them-thus, we have warrant to do so, so long as we do not have sufficient reason to disbelieve the cornerstone in question. ${ }^{35}$ Scepticism about these cornerstones are blocked because these we are non-evidentially entitled to them-the sceptic cannot cast doubt on our evidence for these propositions, because they require none. ${ }^{36}$ These entitlements are typically taken to have an externalist dimension, insofar as our entitlement to cornerstones does not turn on any reasoning we might do, but rather hold in virtue of certain epistemic dependencies independent of our reasoning-thus, such entitlement is said to come 'for free'.

In light of this, we might state Hume's discussion of antecedent scepticism as follows. Consider the proposition 'our cognitive faculties are reliable. This proposition is a cornerstone-to doubt it would undermine any possibility of epistemic achievement whatsoever. And, prior to any investigation (the point at which antecedent scepticism enters the fray), we certainly lack any positive reason to think that this proposition is false. Thus, we are justified in holding this proposition, at least until sufficient positive reason emerges to doubt it. And, like with conservatism, this justification seems to have an externalist dimension. ${ }^{37}$ For, if our reliance on our faculties were justified by a further belief that these faculties were crucial to our epistemological projects, the antecedent sceptic could well ask how we would know that this belief was justified. Without a prior justification of our faculties, we would be at a loss for an answer-trust in our faculties has to be bedrock.

to rely on certain belief-forming processes on the basis that such processes are reliably veridical; see (Burge, 1993), (Burge, 1996), (Burge, 2003). That said, Wright's account seems to much better resemble Hume's dismissal of antecedent scepticism.

34 (Wright, 2004, pp.167-168).

35 (Wright, 2004, p.189).

36 It has been objected that this can only offer pragmatic rather than epistemic reasons for accepting such cornerstones; for instance, see (Jenkins, 2007, p.27), (Pritchard, 2007, p.207), and (Coliva, 2015, p.68). I find persuasive Wright's response, which is that pragmatic reasons are in general instrumental; with regard to cornerstones, these pragmatic reasons are in service of epistemic values, and so these pragmatic reasons are also epistemic in nature (Wright, 2014, p.239).

37 As mentioned in the introduction, previously in (Qu, 2018b) and (Qu, 2020, Ch.9), I have maintained that Hume's epistemology in the Enquiry is internalist in character, but I have recently come to appreciate that it has externalist aspects as well. In particular, while my earlier work treated antecedent justification as internalist, I have come to think it is better characterised as externalist, for the reasons given above. We will later see another respect in which my views on externalism in the Enquiry have moved. 
Importantly, antecedent justification is extremely weak, and has to be. It would be a terrible result if all our faculties were ultima facie justified-after all, we know from experience that some of our belief-forming processes are not entirely reliable. To flesh out the epistemological story, we need a story about defeat: the antecedent justification accorded to our faculties holds unless there is a relevant defeater. What would constitute such a defeater? Once the spectre of antecedent scepticism has been done away with, we now hold the tools with which to conduct a consequent investigation of our faculties. If this investigation finds that our faculties are not reliable (as judged by their own lights), then we will have a good reason to distrust our faculties, and their antecedent justification will be defeated. This leads us to what Hume calls consequent scepticism:

There is another species of scepticism, consequent to science and enquiry, when men are supposed to have discovered, either the absolute fallaciousness of their mental faculties, or their unfitness to reach any fixed determination in all those curious subjects of speculation, about which they are commonly employed. (EHU 12.5; SBN 150)

On the flip side, if this consequent investigation discerns that some of our faculties are indeed reliable, then their antecedent justification is affirmed. We might then say that these faculties enjoy consequent justification.

What constitutes sufficient reason to doubt the reliability of our faculties? Here, standards might vary, corresponding to different forms of scepticism. Hume distinguishes two forms of consequent scepticism: Pyrrhonian or excessive scepticism on the one hand, and mitigated scepticism on the other. I venture that these two forms of scepticism are to be distinguished on the basis of their different standards for defeat with respect to the antecedent justification accorded to our faculties. Hume does not offer an explicit statement of the methodology of Pyrrhonian scepticism, but if we examine its arguments, we will see that Pyrrhonian scepticism has a tendency to be too liberal with its standards for defeat: given a certain misstep from our faculties, the Pyrrhonian will take this to be decisive reason to dismiss it wholesale. Consider a number of arguments Hume produces on behalf of the Pyrrhonian.

The Pyrrhonian sceptic dismisses the reliability of our senses on the basis of the 'trite topics' (EHU 12.6; SBN 151) such as oars appearing bent in water, or double vision upon pressing one's eye. But as Hume points out, this only demonstrates that the senses need to be corrected by reason, not that we cannot rely on them in any context: 'These sceptical topics, indeed, are only sufficient to prove, that the senses alone are not implicitly to be depended on; but that we must correct their evidence by reason' (ibid.).

The Pyrrhonian sceptic also doubts the veracity of our senses on the basis of scepticism arising from the basis of the doctrine of double existence: our instincts tell us that our perceptions of sensation are external objects (EHU 12.8; SBN 151-2), but reason contradicts this claim (EHU 
12.9; SBN 152), leading philosophers to postulate that these perceptions are caused by external objects (EHU 12.11; SBN 152-3). But this is a thesis that is beyond the scope of our faculties, being a matter of fact that cannot be justified by experience (EHU 12.12; SBN 153). The doctrine of double existence also gives rise to the theory of primary and secondary qualities, which leads to problems with regard to abstraction (EHU 12.15; SBN 154-5). Yet we might respond: while these rarefied philosophical theses might be problematic, why should this cast any doubt on the first-order deliverances of our senses?

The Pyrrhonian sceptic also doubts all abstract reasoning merely on the basis of paradoxes regarding infinite divisibility (EHU 12.18; SBN 1567). Granted that we might need to avoid abstruse reasoning about infinite divisibility, but surely the Pyrrhonian overreacts: can we not be confident of simple arithmetical calculations, for instance?

The Pyrrhonian sceptic, via the 'popular' argument, doubts all probable reasoning on the basis that there is a significant degree of variation amongst inductive judgments (EHU 12.21; SBN 158-9). But this is clearly an insufficient basis on which to doubt wholesale our probable reasoning: what about the many more instances whereby people agree, and are correct, in their probable judgments?

The Pyrrhonian sceptic, via the 'philosophical' argument, argues for the unreliability of custom, because it is an instinct, and 'other instincts' have proven 'fallacious and deceitful' (EHU 12.22; SBN 159). But this seems egregious: why should the fallaciousness of unrelated instincts bear on the reliability of custom? Indeed, as we saw at the close of Section 5, Hume thinks that we do have significant positive evidence for custom being truthconducive.

Pyrrhonian scepticism is thus unsatisfactory. ${ }^{38}$ Hume proposes in its place mitigated scepticism, which advocates the limitation of the scope of our enquiries: ${ }^{39}$

Another species of mitigated scepticism, which may be of advantage to mankind, and which may be the natural result of the Pyrrhonian doubts and scruples, is the limitation of our enquiries to such subjects as are best adapted to the narrow capacity of human understanding. (EHU 12.25; SBN 162)

38 Hume explicitly adduces pragmatic reasons to dismiss Pyrrhonian scepticism: namely its unsustainability, and its dangerousness were it sustainable (EHU 12.23; SBN 159-60). But these do not offer any epistemic reason for dismissing Pyrrhonian scepticism. Although the epistemic reasons are implicit, I think they are no less present.

39 Another aspect of mitigated scepticism is the general adoption of a degree of epistemic humility in lowering our credences across the board, since we are naturally disposed to overconfidence (EHU 12.24; SBN 161-2), which is sensible advice, but perhaps less systematically interesting for our purposes here. 
In this, we can see mitigated scepticism as deriving naturally from the flaws of Pyrrhonian scepticism-Hume notes that such scepticism is 'the result of... Pyrrhonism, or excessive scepticism, when its undistinguished doubts are, in some measure, corrected by common sense and reflection' (EHU 12.24; SBN 161). Pyrrhonian scepticism, in taking any small imperfection to count as a relevant defeater for the reliability of that faculty, overgeneralises sceptical doubt on the basis of relatively thin evidence of the unreliability of our senses. Meanwhile, mitigated scepticism is more judicious in this respect. Hume's exhortation to remain exactly within the boundaries of 'subjects as are best adapted' to our faculties chides the Pyrrhonian for its trigger-happy approach to consequent scepticism. In doubting wholesale the reliability of our faculties on such a meagre basis, the Pyrrhonian decidedly understeps the scope of our faculties. Particularly egregious are the cases whereby the Pyrrhonian doubts a faculty on the basis of enquiries that overstep the boundaries of human knowledge, such as scepticism arising from the doctrine of double existence, or scepticism regarding infinite divisibility. For these surely offer no reason to doubt our faculties with respect to more prosaic matters. In response to these two flaws of the Pyrrhonian, mitigated scepticism proposes a 'Goldilocks' solution: we should not overstep or understep the boundaries of our faculties, but remain exactly within their scope. Thus, mitigated scepticism recognises that many of our belief-forming processes enjoy consequent justification; lacking sufficient reason to think them unreliable, their antecedent justification is not defeated.

The above points to consequent scepticism having a reliabilistic strain running through it. Key to a belief-forming operation enjoying consequent justification is our verifying its truth-conduciveness. If we find a faculty or operation to be reliable, then its antecedent justification is not defeated; but if we find it to be unreliable, then its antecedent justification is defeated. Importantly, on such a view, it seems that evidence regarding a faculty's reliability is necessary for its enjoying consequent justification.

At the same time, consequent justification seems to have an internalistic aspect to it. Mitigated scepticism, as a brand of consequent scepticism, arises as a result of an investigation into the reliability of our faculties, as Hume earlier notes in EHU 12.5 (SBN 150-1), and again in EHU 12.26 (SBN 163):

This narrow limitation, indeed, of our enquiries, is, in every respect, so reasonable, that it suffices to make the slightest examination into the natural powers of the human mind, and to compare them with their objects, in order to recommend it to us. (EHU 12.26; SBN 163)

Correspondingly, the consequent justification granted by mitigated scepticism likewise arises as a result of such enquiry, and thus is mentally available to us. What is crucial for epistemic justification is not so much whether our faculties are actually reliable, but whether we find them to be such. 
I have previously argued that Hume's account of consequent justification resembles an epistemological framework called 'internalist reliabilism' (Steup, 2004). ${ }^{40}$ Briefly, Steup argues that our perceptual experiences are sources of justification insofar as we have memory impressions of both the reliability of our senses and of our memory (p.408). While putting reliability at the forefront, this account is internalist insofar as justification derives not from the reliability of the underlying belief-forming processes that produce it per $s e$, but rather our evidence of the reliability of these underlying processes, via our memory of their track record. Again, a prominent difference with Hume's framework is that, like many foundationalist accounts, Steup accords a special status to the senses and perceptual experiences, while Hume is concerned with our faculties more broadly. But there is a distinct resemblance between these two frameworks.

That having been said, a number of ostensibly externalist reliabilist accounts have adopted internalist-friendly elements. One such example is (Alston, 1988), which seeks to integrate evidentialism and reliabilism. ${ }^{41}$ Notably for our purposes, while maintaining that epistemic justification sources from truth-conduciveness (p.278), Alston also maintains that the grounds for justification must be 'the sort of thing' that is available to the agent, even if not in fact thusly available (p.274).

In line with such accounts, I have come to think that another useful analogue for Hume's epistemology in the Enquiry is what has been called 'approved-list reliabilism. ${ }^{42}$ This view holds that beliefs are deemed to be justified if they issue from belief-forming processes that are designated as epistemically virtuous (they are 'on the approved list'), and these beliefforming processes are thusly designated if they are found to be reliable. This certainly seems a fair characterisation of Hume's framework in Section 12, as described above. Consequent investigation establishes which faculties are reliable and thus enjoy consequent justification. Those that do, go on the list, and beliefs that issue from them are correspondingly deemed justified.

40 (Qu, 2018b), (Qu, 2020, pp.223-224).

41 Other reliabilist views that incorporate internalist elements are as follows. (Tang, 2016) offers a development of Alston's account that applies to credences, which might be thought to fruitfully mirror the degrees of vivacity a Humean belief may possess. (Comesana, 2010) defends a view entitled 'evidentialist reliabilism', according to which a belief is justified if it is based on evidence, and the belief-forming process that produces it based on that evidence is reliable. Likewise, (Goldman, 2012) proposes an evidentialist framework that cashes out evidence partly in terms of reliability-this is a two-factor approach, whereby justification turns both on fit with experiential evidence and causation by a reliable experience-based process (p.146). In similar vein is (Henderson, Terry, \& Potre, 2007). Rather than integrating reliabilism with evidentialism, (Beddor, Forthcoming) proposes an integration with a reasons-based framework, arguing that it makes for a superior account of defeat.

42 (Goldman, 1993), (Fricker, 2016). I think of it as 'Santa-reliabilism'-he's making a list, and checking it twice. 
It is true that approved-list reliabilism is not in itself an internalist theory: what matters for epistemic justification is simply whether a particular belief-forming process is on the approved list or not. Yet such a theory still gives a crucial role to the investigation of the reliability of our faculties in determining what goes into this list, respecting the internalistic aspect of Hume's framework in the Enquiry. ${ }^{43}$

Still, there is a deeper and more intriguing connection between the two. 'Approved-list reliabilism', as Goldman defends it (although he does not use the term), is an exercise in 'descriptive epistemology', rather than a 'normative epistemology'. ${ }^{44}$ A descriptive epistemology seeks to 'elucidate commonsense epistemic concepts and principles', while a normative epistemology looks to formulate 'a more adequate, sound, or systematic set of epistemic norms, in some way(s) transcending our naïve epistemic repertoire. ${ }^{45}$ In short, we might think of a descriptive epistemology as offering an account of justificationascriptions, rather than justification proper.

However, for Hume, the gap between these two projects is narrower than it would be for most. In general, we might convert approved-list reliabilism into a normative theory by adding the normative claim that a belief is justified iff it is on the approved list of most normal speakers at the actual world. Hume's normative methodology suggests that this would be an addition that he would be comfortable with. When explaining his own positive epistemology, he explicitly states: 'philosophical decisions are nothing but the reflections of common life, methodised and corrected' (EHU 12.25; SBN 162). As I have argued elsewhere, Hume's normative project consists of the systematisation of our pre-philosophical normative judgments into a sound and cohesive system. ${ }^{46}$ This is a direct result of Hume's account of normativity as essentially founded on sentiment. We deem an act to be moral because it derives from a virtue that excites sentiments of approbation; similarly with a wise judgment. Thus, to derive a true theory of morality or epistemology, Hume looks to systematise the deliverances of our normative sentiments. Indeed, Hume describes his methodology in the moral Enquiry as consisting of analysing 'that complication of mental qualities, which... we call Personal Merit' (EPM 1.10). He continues:

The only object of reasoning is to discover the circumstances on both sides, which are common to these qualities; to observe that particular in which the estimable qualities agree on the one hand, and the blameable on the other, and thence to reach the foundation of ethics, and find

43 This is another respect in which my views on externalism in Hume's Enquiry have moved, as alluded to earlier. While internalist reliabilism is an unapologetically internalist theory, approved-list reliabilism is an externalist one (albeit with internalist elements).

44 (Goldman, 1993, p.282).

45 (Goldman, 1993, pp.271-273).

46 The nuts and bolts of this systematising project are spelt out in (Qu, 2016). 
those universal principles, from which all censure or approbation is ultimately derived. (EPM 1.10; SBN 174)

Hume's task is descriptive in Goldman's sense, but it is also normative. The two are intertwined: to describe and systematise our normative judgments is to produce a genuinely prescriptive epistemology. Just as he seeks to offer an account of virtue and vice in the moral domain via a study of our moral intuitions, he can be read as looking to provide an account of epistemic justification via a study of our epistemological intuitions.

\section{The Generality Problem}

There are a number of worries at this juncture. First, it might be worried that there is a circularity involved in using our faculties to justify themselves. I have addressed this worry elsewhere, ${ }^{47}$ but briefly, circularity is avoided because of the distinction between two types of justification: antecedent and consequent. Antecedent justification is leveraged in order to attain consequent justification, which avoids epistemic circularity. 48

We have seen that there is a strain of reliabilist thought that runs through the Enquiry in particular. Yet, in this, Hume's framework in this later work correspondingly inherits the problems of reliabilism as well. I wish to conclude the paper by considering one such inherited worry-the generality problem. ${ }^{49}$ The generality problem is often raised as an objection to reliabilism, although commentators have argued that its scope is much broader. ${ }^{50}$ The problem at its heart is as follows. A given belief is the result of a process-token that can be typed in a large array of ways. My belief that there is a tree in front of me can be characterised as the result of perception, perception under such-andsuch lighting, perception of tree-like objects, perception of natural objects, and so forth. Without a unique way of settling which process-type is relevant to a given epistemic evaluation, we will be unable to get a reliabilist theory off the ground.

47 (Qu, 2020, p.201).

48 Thus, this avoids accusations of illegitimate bootstrapping, which is problematic precisely because it embodies an epistemic circularity; for instance, see (Vogel, 2000). Hume does bootstrap, but it is benign. There are two further considerations to note in this regard. One is that Hume is not alone in this regard: (Cohen, 2002) has argued that bootstrapping afflicts all theories that take on a 'basic knowledge' structure (that is, theories that allow for a belief source to deliver knowledge prior to knowing that the source is reliable). Second, (Van Cleve, 2003) argues persuasively that bootstrapping cannot be avoided on pain of falling to excessive scepticism, and defends a form of it, indeed interpreting Reid as doing the same. This I take to be Hume's response as well. As Hume sees it, the choice is between antecedent scepticism and bootstrapping, and he chooses accordingly.

49 The classic statements of this problem are (Feldman, 1985) and (Conee \& Feldman, 1998).

50 (Comesana, 2006), (Bishop, 2010), (Tolly, 2017). 
This is a critical (arguably the most critical) problem for reliabilism and beyond, and it would be unrealistic to expect Hume to have an answer for it, centuries before either reliabilism or the generality problem were prominent. Indeed, there is little indication that he was aware of the problem at all; at most, he gestures at it when rejecting the policy of forbidding all abstruse reasoning partly on the basis that such a policy would be unprincipled in allowing some but not all principles of the imagination (THN 1.4.7.7; SBN $267-8) .{ }^{51}$

I have argued that nevertheless, Hume might have a putative response available: in this respect, epistemology should take its cue from psychology. ${ }^{52}$ Hume proposes a 'mental geography, or delineation of the distinct parts and powers of the mind' (EHU 1.13; SBN 13); insofar as this endeavour is successful, we can use its results to determine the appropriate process-types. This is in line with some contemporary responses to the generality problem that appeal to psychological means of winnowing down process-typesprocess-types that do not play a causal role in the subject's psychology should be dismissed. ${ }^{53}$

However, this does not seem to get us all the way to uniqueness, for it leaves open a range of psychological process-types. ${ }^{54}$ For instance, take the belief that the mangosteen tree will bear fruit. Just according to Hume's psychological framework, this belief could be described as issuing from custom, probable reasoning, reason, or the imagination (in the broad sense). All of these belief-forming processes carve at the psychological joints, according to Hume, and the generality problem remains.

Perhaps we can do a little better yet on Hume's behalf. Recall from earlier that Hume's epistemological project involved systematising our common-sensical epistemological intuitions. These intuitions will include intuitions about which belief-forming processes are epistemically relevant. For instance, the imagination (in the broad sense) will clearly seem too broad to be epistemically relevant to my belief that a mangosteen tree will bear fruit. We might fruitfully appeal to these intuitions to further triangulate the epistemically relevant belief-forming processes. This is akin to a solution offered by Schmitt, which argues that to solve the generality problem, it is not required that the reliabilist provide necessary and sufficient conditions for the relevance of types; rather, it suffices to simply provide some constraints on relevant factors. ${ }^{55}$ This is because reliabilism can be supplemented by our

51 Although (Schmitt, 1992, p.140) sees this problem as weighing more heavily on Hume's mind than I do.

$52(\mathrm{Qu}, 2020, \mathrm{p} .202)$.

53 (Alston, 1995), (Beebe, 2004), (Kampa, 2018), (Lyons, 2019).

54 (Conee \& Feldman, 1998, pp.10-18). Beebe, Kampa, and Lyons offer sophisticated versions of the psychological approach that seek to deliver uniqueness, but these are quite distant from anything we can find in Hume.

55 (Schmitt, 1992, Ch.6), although see (Conee \& Feldman, 1998, pp.18-20) for criticism. 
common-sensical epistemological intuitions as to the relevance of processes. ${ }^{56}$ In Hume's case, he has derived a systematised account of these intuitions, and he is licensed to make use of it in resolving the generalist problem without begging the question.

Importantly, by synthesising this normative carving of our belief-forming processes with Hume's psychological carving of the same, we can triangulate the relevant belief-forming processes for a given belief. This narrows down the field of options considerably more than merely psychological solutions. Is this cross-referencing approach sufficient to solve the generality problem? Perhaps, perhaps not. But as we have seen, it would be unreasonable to expect Hume to have a complete solution to this problem to hand. At the very least, he has the resources to make progress on such a solution. And can we ask for much more than that of Hume? In many ways, his thought remains relevant to some of the most cutting-edge developments in philosophy today. ${ }^{57}$

\section{References}

Ainslie, D. (2015). Hume’s True Scepticism. Oxford: Oxford University Press.

Allison, H. (2008). Custom and Reason in Hume: A Kantian Reading of the First Book of the Treatise. Oxford: Oxford University Press.

Alston, W. (1988). An Internalist Externalism. Synthese, 74(3), 265-283.

Alston, W. (1995). How to Think about Reliability. Philosophical Topics, 23(1), $1-29$.

Baxter, D. (2018). A Pyrrhonian Interprettion of Hume on Assent. In D. E. Machuca \& B. Reed (Eds.), Skepticism: From Antiquity to the Present (pp. 380-394). New York: Bloomsbury.

Beddor, R. (Forthcoming). Reasons for Reliabilism. In J. Brown \& M. Simion (Eds.), Reasons, Justification, and Defeat: Oxford University Press.

Beebe, J. (2004). The Generality Problem, Statistical Relevance and the TriLevel Hypothesis. Noûs, 38(1), 177-195.

Beebee, H. (2006). Hume on Causation. London: Routledge.

Bishop, M. A. (2010). Why the Generality Problem is Everybody's Problem. Philosophical Studies, 151(2), 285-298.

Brogaard, B. (2013). Phenomenal Seemings and Sensible Dogmatism. In C. Tucker (Ed.), Seemings and Justification: New Essays on Dogmatism and Phenomenal Conservatism (pp. 270-289). New York: Oxford University Press.

56 (Schmitt, 1992, pp.141-142).

57 Thanks to Frederick Schmitt, Bob Beddor, and Tang Weng Hong for very helpful and detailed comments on an earlier draft of the paper. 
Broughton, J. (1983). Hume's Skepticism about Causal Inferences. Pacific Philosophical Quarterly, 64, 3-18.

Burge, T. (1993). Content Preservation. Philosophical Review, 102(4), 457-488.

Burge, T. (1996). Our Entitilement to Self-Knowledge. Proceedings of the Aristotelian Society, 96(1), 91-116.

Burge, T. (2003). Perceptual Entitilement. Philosophy and Phenomenological Research, 67(3), 503-548.

Chudnoff, E. (2013). Intuition. Oxford: Oxford University Press.

Cohen. (2002). Basic Knowledge and the Problem of Easy Knowledge. Philosophy and Phenomenological Research, 65(2), 309-329.

Coliva, A. (2015). Extended Rationality: A Hinge Epistemology. London: Palgrave Macmillan.

Comesana, J. (2006). A Well-Founded Solution to the Generality Problem. Philosophical Studies, 129(1), 27-47.

Comesana, J. (2010). Evidentialist Reliabilism. Noûs, 44(4), 571-600.

Conee, E., \& Feldman, R. (1998). The Generality Problem for Reliabilism. Philosophical Studies, 89, 1-29.

Costa, M. A. (1981). Hume and Justified Belief. Canadian Journal of Philosophy, 11, 219-228.

Dauer, F. W. (1980). Hume's Skeptical Solution and the Causal Theory of Knowledge. Philosophical Review, 89, 357-378.

Dimech, D. (Forthcoming). Quasi-Realism and Inductive Scepticism in Hume's Theory of Causation. Australasian Journal of Philosophy.

Dretske, F. (1981). Knowledge and the Flow of Information. Cambridge: MIT Press.

Durland, K. (2011). Extreme Skepticism and Commitment in the Treatise. Hume Studies, 37(1), 65-98.

Feldman, R. (1985). Reliability and Justification. The Monist, 68(2), 159-174.

Feldman, R., \& Conee, E. (2001). Internalism Defended. American Philosophical Quarterly, 38(1), 1-18.

Fricker, E. (2016). Unreliable Testimony. In B. Mclaughlin \& H. Kornblith (Eds.), Goldman and His Critics (pp. 88-123). Oxford: Wiley Blackwell.

Garrett, D. (1997). Cognition and Commitment in Hume's Philosophy. New York: Oxford University Press.

Garrett, D. (1998). Ideas, Reasons, and Scepticism: Response to my Critics. Hume Studies, 24(1), 171-194. 
Garrett, D. (2006). Hume's Conclusions in 'Conclusion of this Book'. In S. Traiger (Ed.), The Blackwell Guide to Hume's Treatise (pp. 151-176). Oxford: Wiley-Blackwell.

Garrett, D. (2007). Reasons to act and believe: naturalism and rational justification in Hume's philosophical project. Philosophical Studies, 132(1), 1-16. doi:10.1007/s11098-006-9055-y

Garrett, D. (2015). Hume. New York: Routledge.

Garrett, D. (2016). Hume on Reason, Normativity, and the Title Principle. In P. Russell (Ed.), The Oxford Handbook of Hume (pp. 32-53). New York: Oxford University Press.

Goldman, A. (1967). A Causal Theory of Knowing. Journal of Philosophy, 64(12), 357-372.

Goldman, A. (1979). What is Justified Belief? In G. Pappas (Ed.), Justification and Knowledge (pp. 1-25). Dordrecht: Reidel.

Goldman, A. (1993). Epistemic Folkways and Scientific Epistemology. Philosophical Issues, 3, 271-285.

Goldman, A. (2012). Towards a Synthesis of Reliabilism and Evidentialism? In A. Goldman (Ed.), Reliabilism and Contemporary Epistemology: Essays (pp. 123-150). New York: Oxford University Press.

Greco, J. (2012). Achieving Knowledge. Cambridge: Cambridge University Press.

Henderson, D., Terry, H., \& Potre, M. (2007). Transglobal EvidentialismReliabilism. Acta Analytica, 22, 281-300.

Huemer, M. (2001). Skepticism and the Veil of Perception. Lanham, MD: Rowman and Littlefield.

Huemer, M. (2007). Compassionate Phenomenal Conservatism. Philosophy and Phenomenological Research, 74(1), 30-55.

Huemer, M. (2013). Phenomenal Conservatism Über Alles. In C. Tucker (Ed.), Seemings and Justification: New Essays on Dogmatism and Phenomenal Conservatism (pp. 328-350). Oxford: Oxford University Press.

Hume, D. (1739-1740/2007). A Treatise of Human Nature (D. F. Norton \& M. J. Norton Eds.). Oxford; New York: Oxford University Press.

Hume, D. (1748/2007). An Enquiry Concerning Human Understanding (P. Millican Ed.). Oxford: Oxford University Press.

Hume, D. (1751/1998). An Enquiry Concerning the Principles of Morals (T. L. Beauchamp Ed.). Oxford: Oxford University Press.

Jenkins, C. (2007). Entitlement and Rationality. Synthese, 157(1), 25-45.

Kail, P. (2007). Projection and Realism in Hume's Philosophy. Oxford: Oxford University Press. 
Kail, P. (2016). Hume's 'Manifest Contradictions'. Royal Institute of Philosophy Supplement, 78, 147-160.

Kampa, S. (2018). A New Statistical Solution to the Generality problem. Episteme, 15(2), 228-244.

Loeb, L. E. (2002). Stability and Justification in Hume's Treatise. Retrieved from http://dx.doi.org/10.1093/0195146581.001.0001

Loeb, L. E. (2006). Psychology, Epistemology, and Scepticism in Hume's Argument about Induction. Synthese, 152(3), 321-338.

Loeb, L. E. (2008). Inductive Inference in Hume's Philosophy. In E. S. Radcliffe (Ed.), A Companion to Hume (pp. 106-125). Oxford: Wiley-Blackwell.

Loeb, L. E. (2011). Epistemological Commitment in Hume's Treatise. Oxford Studies in Early Modern Philosophy, 6, 309-247.

Lyons, J. (2019). Algorithms and Parameters: Solving the Generality problem for Reliabilism. The Philosophical Review, 128(4), 463-509.

Marusic, J. S. (2010). Does Hume Hold a Dispositional Account of Belief? Canadian Journal of Philosophy, 40(2), 155-184.

McAllister, B. (2018). Seemings as Sui Generis. Synthese, 195, 3079-3096.

Meeker, K. (2013). Hume's Radical Scepticism and the Fate of Naturalized Epistemology. Basingstoke: Palgrace Macmillan.

Millican, P. (1995). Hume's Argument Concerning Induction: Structure and Interpretation. In S. Tweyman (Ed.), David Hume: Critical Assessments (pp. 91-144). London and New York: Routledge.

Millican, P. (2002). Hume's Sceptical Doubts concerning Induction. In P. Millican (Ed.), Reading Hume on Human Understanding (pp. 107-174). Oxford: Oxford University Press.

Millican, P. (2012). Hume's 'Scepticism' About Induction. In A. O. B. Bailey, Dan (Ed.), The Continuum Companion to Hume (pp. 57-103). New York: Bloomsbury Academic.

Millican, P. (2016). Hume's Chief Argument. In P. Russell (Ed.), The Oxford Handbook of Hume (pp. 82-108). New York: Oxford University Press.

Mounce, H. (1999). Hume's Naturalism. London: Routledge.

Noonan, H. (1999). Hume on Knowledge. London: Routledge.

Owen, D. (1999). Hume's Reason. Retrieved from http://dx.doi.org/10.1093/ 0199252602.001.0001

Pritchard, D. (2007). Wittgenstein's On Certainty and Contemporary AntiScepticism. In D. Moyal-Sharrock \& W. H. Brenner (Eds.), Readings of Wittgenstein's On Certainty (pp. 189-224). Basingstoke: Palgrave Macmillan. 
Pryor, J. (2000). The Skeptic and the Dogmatist. Nô̂s, 34(4), 517-549.

Pryor, J. (2004). What's Wrong With Moore's Argument? Philosophical Issues, 14(1), 349-378.

Qu, H. (2014a). Hume's Positive Argument on Induction. Nô̂s, 48(4), 595625. doi:10.1111/nous. 12015

Qu, H. (2014b). Hume's Practically Epistemic Conclusions? Philosophical Studies, 170(3), 501-524. doi:10.1007/s11098-013-0260-1

Qu, H. (2016). Prescription, Description, and Hume's Experimental Method. British Journal for the History of Philosophy, 24(2), 1-23. doi:10.1080/0960 8788.2015.1134438

Qu, H. (2017). Hume’s Doxastic Involuntarism. Mind, 126, 53-92.

Qu, H. (2018a). Hume's (Ad Hoc?) Appeal to the Calm Passions. Archiv für Geschichte der Philosophie, 100(4), 444-469.

Qu, H. (2018b). Hume's Internalism in EHU 12. Philosophy and Phenomenological Research, 96(3), 517-539.

Qu, H. (2020). Hume's Epistemological Evolution. New York: Oxford University Press.

Sasser, N. (Forthcoming). Hume's Purely Practical Response to Philosophical Scepticism. Hume Studies.

Schafer, K. (2014). Curious Virtues in Hume's Epistemology. Philosophers' Imprint, 14(1), 1-20.

Schmitt, F. (1992). Knowledge and Belief. London: Routledge \& Kegan Paul.

Schmitt, F. (2014). Hume's Epistemology in the Treatise. Oxford: Oxford University Press.

Shaw, D. (1989). Hume's Theory of Motivation. Hume Studies, 15(1), 163-183.

Smith, M. (1994). The Moral Problem. Oxford: Blackwell Publishing.

Steup, M. (2004). Internalist Reliabilism. Philosophical Issues, 14(1), 403-425.

Stroud, B. (1977). Hume. London: Routledge and Kegan Paul.

Tang, W. H. (2016). Reliability Theories of Justified Credence. Mind, 125(497), 63-94.

Teng, L. (2018). Is Phenomenal Force Sufficient for Immediate Justification? Synthese, 195, 637-656.

Tolhurst, W. (1998). Seemings. American Philosophical Quarterly, 35(3), 293-302.

Tolly, J. (2017). A Defence of Parrying Responses to the Generality Problem. Philosophical Studies, 174(8), 1935-1957. 
Tucker, C. (2010). Why Open-Minded People Should Endorse Dogmatism. Philosophical Perspectives, 24, 529-545.

Van Cleve, J. (2003). Is Knowledge Easy-Or Impossible? Externalism as the Only Alternative to Skepticism. In S. Luper (Ed.), The Skeptics: Contemporary Essays (pp. 45-60). Aldershot: Ashgate.

Vogel, J. (2000). Reliabilism Leveled. Journal of Philosophy, 91(1), 602-623.

Werner, P. (2014). Seemings: Still Dispositions to Believe. Synthese, 191, $1761-1774$.

Winkler, K. (1999). Hume's Inductive Scepticism. In M. Atherton (Ed.), The Empiricists: Locke, Berkeley, and Hume (pp. 183-212). Oxford: Rowman and Littlefield Publishers.

Wright, C. (2002). (Anti-)sceptics simple and subtle: Moore and McDowell. Philosophy and Phenomenological Research, 65(2), 330-348.

Wright, C. (2004). On Epistemic Entitlement: Warrant for Nothing (and Foundations for Free?). The Aristotelian Society, Supplementary Vol. 78(1), $167-212$.

Wright, C. (2014). On Epistemic Entitlement (II): Welfare State Epistemology. In D. Dodd \& E. Zardini (Eds.), Scepticism and Perceptual Justification (pp. 213-247). Oxford: Oxford University Press. 